\title{
Tumor burden and location as prognostic factors in patients treated by iodine seed implant brachytherapy for localized prostate cancers
}

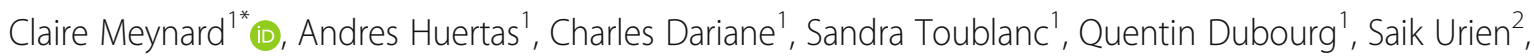
Marc-Olivier Timsit ${ }^{1}$, Arnaud Méjean ${ }^{1}$, Nicolas Thiounn ${ }^{1}$ and Philippe Giraud ${ }^{1}$

\begin{abstract}
Background: lodine seed implant brachytherapy is indicated for low risk and selected favorable intermediate risk prostate cancers. A percentage of positive biopsies $>50 \%$ is usually considered as a contra-indication, and the tumor location could also influence the treatment efficacy. We studied the association of the percentage of positive biopsy cores, and tumor location, with progression-free survival.

Methods: Among the 382 patients treated at our center by permanent implant iodine seed brachytherapy for a localized prostate cancer between 2006 and 2013, 282 had accessible detailed pathology reports, a minimum follow-up of 6 months, and were included. Progression was defined as a biochemical, local, nodal, or distant metastatic relapse. We studied cancer location on biopsies (base, midgland or apex of the prostate) and percentage of positive biopsy cores, as well as potential confounders (pre-treatment PSA, tumor stage, Gleason score, risk group according to D'Amico's classification modified by Zumsteg, adjunction of androgen deprivation therapy, and dosimetric data).

Results: Most patients (197; 69.9\%) had a low risk, 67 (23.8\%) a favorable intermediate risk, 16 (5.7\%) an unfavorable intermediate risk, and $1(0.3 \%)$ a high-risk prostate cancer. An involvement of the apex was found for 131 patients (46,5\%), of the midgland for $149(52,8 \%)$, and of the base for $145(51,4 \%)$. The median percentage of positive biopsy cores was 17\% [3-75\%]. The median follow-up was 64 months [12-140]. Twenty patients (7\%) progressed: 4 progressions (20\%) were biochemical only, 7 (35\%) were prostatic or seminal, 6 (30\%) were nodal, and 3 (15\%) were metastatic. The median time to failure was 39.5 months [9-108]. There were more Gleason scores $\geq 7$ among patients who progressed (40\% vs $19 \% ; p=0.042$ ). None of the studied covariates (including tumor location, and percentage of positive biopsy cores), were significantly associated with progression-free survival. The risk group showed a trend towards an association ( $p=0.055)$.

Conclusions: Brachytherapy is an efficient treatment (5-year control rate of 93\%) for patients carefully selected with classical criteria. The percentage and location of positive biopsies were not significantly associated with progression-free survival. A Gleason score $\geq 7$ was more frequent in case of progression.
\end{abstract}

Keywords: Prostate cancer, lodine seed implant brachytherapy, Prostate biopsies, Tumor burden, Gleason score, Risk groups

\footnotetext{
* Correspondence: clairemeynard@hotmail.fr

${ }^{1}$ Hôpital Européen Georges Pompidou, 20 rue Leblanc, 75015 Paris, France

Full list of author information is available at the end of the article
}

(c) The Author(s). 2019 Open Access This article is distributed under the terms of the Creative Commons Attribution 4.0 International License (http://creativecommons.org/licenses/by/4.0/), which permits unrestricted use, distribution, and reproduction in any medium, provided you give appropriate credit to the original author(s) and the source, provide a link to the Creative Commons license, and indicate if changes were made. The Creative Commons Public Domain Dedication waiver (http://creativecommons.org/publicdomain/zero/1.0/) applies to the data made available in this article, unless otherwise stated. 


\section{Background}

Low-dose rate prostate brachytherapy, with permanent implant of Iodine-125 seeds, is an effective treatment for patients with low to intermediate-risk localized prostate cancer [1-4]. The safety profile of brachytherapy makes it an interesting alternative to radical prostatectomy and external beam radiation therapy $[5,6]$, and its good results in terms of oncological outcome [7-10] make it an attractive alternative to active surveillance too, for patients refusing it.

Brachytherapy is recommended for patients with low-risk prostate cancer and selected favorable intermediate risk prostate cancer (with only one factor of intermediate risk among a Gleason score of $7(3+4)$ and a pre-treatment PSA serum level between 10 and $15 \mathrm{ng} / \mathrm{mL}$ ) [11, 12]. Patients should also have an International Prostatic Symptom Score (IPSS) of 12 or less, and a prostatic volume of less than $50 \mathrm{cc}$ [11].

Some guidelines include a threshold on the percentage of positive prostate biopsy cores, which should not exceed $50 \%$ [13]. It is even restricted to $33 \%$ for patients with a Gleason score of 7, according to other guidelines [14]. The percentage of positive biopsies has been shown to be associated with biochemical outcome after prostatectomy, and after external-beam radiation therapy [15]. Concerning brachytherapy, although some retrospective studies showed a relationship between the percentage of positive biopsies and the biochemical progression free survival [16-20], this threshold of $50 \%$ of positive prostate biopsies is not commonly admitted.

Another limitation that is sometimes considered when treating a prostate cancer with brachytherapy, is the location of the cancer in the prostate gland. Classically, the prostate gland is divided into six sextants, by splitting it into left and right, and into three equal segments along the longest sagittal dimension (base, midgland, and apex).

The appropriateness of brachytherapy for cancers involving the base of the prostate has been questioned [21]. The prostate base has indeed been shown to be less well covered with brachytherapy [22]. There are several explanations for this underdosage of the prostate base. First is the proximity of the bladder neck, which must be spared to avoid urinary toxicity [23]. Second is the difficulty in contouring the prostate base with ultra-sound images [24]. Additionally, seed location is more hazardous in the prostate base, due to greater seed displacements [25], loss in the voided urines and lung embolization [26], and because of needle splay (needle divergence, affecting mostly the distribution of superior sources) and needle drag (sources dragged by the needles when pulled back, resulting in a position that is inferior to the initially intended coordinates) [26, 27].

This study aims at reporting the importance of prostate cancer location, from diagnostic prostate biopsies, and percentage of positive biopsy cores, in predicting relapse for patients treated with low-dose rate brachytherapy.

\section{Methods}

\section{Patients}

We retrospectively reviewed the medical records of all patients who were treated at the radiotherapy department of the European Hospital Georges Pompidou with permanent low-dose Iodine seed implant brachytherapy for a newly diagnosed localized prostate cancer between 2006 and 2013.

Patients with available detailed pre-treatment pathology reports and a minimum follow-up of 6 months were included. Written consent was obtained from all patients.

All patients were classified, according to the D'Amico classification [28], into low-risk disease (clinical tumor stage $\leq \mathrm{T} 2 \mathrm{a}$, PSA serum level $<10 \mathrm{ng} / \mathrm{mL}$, and Gleason score $\leq 6$ ), intermediate-risk disease (clinical stage $\mathrm{T} 2 \mathrm{~b}$, PSA between 10 and $20 \mathrm{ng} / \mathrm{mL}$, or Gleason score of $7(3+$ 4 or $4+3)$ ), or high risk-disease (clinical stage $\geq \mathrm{T} 2 \mathrm{c}$, PSA $>20 \mathrm{ng} / \mathrm{mL}$, or Gleason $\geq 8$ ). The intermediate risk disease category was subclassified, according to Zumsteg [29], into favorable intermediate risk disease (only one factor of intermediate risk disease, Gleason $\leq 7(3+4)$, and percentage of positive biopsy cores $<50 \%$ ), and unfavorable intermediate risk disease (intermediate risk disease that cannot be classified as favorable intermediate risk disease). Another risk group classification was studied, using the same criteria except for the tumor stage, which was radiological instead of clinical.

\section{Patient evaluation}

For all patients, the prostate cancer had been clinically staged using medical history, physical examination (including digital rectal examination), and serum PSA measurements. Urinary function was evaluated with the IPSS questionnaire and erectile and bowel functions were assessed during patient interview. A prostate MRI was realized for all patients in our cohort but one.

Pathologic confirmation of the diagnosis of prostate adenocarcinoma was obtained for all patients with ultrasound guided biopsies.

\section{Treatment}

All patients received permanent low-dose Iodine seed implant brachytherapy with a curative intent. Treatment planning was done at the time of the procedure, with Variseed planning software (Varian medical systems, Palo Alto, CA). The prescription dose was $160 \mathrm{~Gy}$. The treatment volume included the whole prostate. The implantation procedure was performed with 18-gauge needles by a radiation oncologist and a urologist, in collaboration. Delineation of the prostate, needle insertion and seed placement were performed under transrectal sonographic guidance using a transperineal template. Needles were loaded manually with loose seeds containing permanent Iodine-125 sources (with an 
activity of $0.4935 \mathrm{mCi} / \mathrm{seed})$. Upon completion of the procedure, patients underwent an immediate anterior Xray. Prostate coverage was also evaluated more precisely with a CT-scan (immediately and at one month for patients treated before 2018, then at 2 months only).

Androgen deprivation therapy was offered before brachytherapy for cytoreductive purpose at physician's discretion.

The dosimetric parameters evaluated included the D90 (the minimum dose received by $90 \%$ of the volume), the V100 (percentage of the volume receiving $100 \%$ of the prescribed dose) and the V150 (percentage of the volume receiving $150 \%$ of the prescribed dose) for the target volume; the D10 (the minimum dose received by $10 \%$ of the volume) and D30 (the minimum dose received by $30 \%$ of the volume) for the urethra. Unfortunately, the sector analysis by sextant for these dosimetric parameters was not available.

\section{Follow-up}

Patients were monitored with physical examination and PSA level measurements every 6 months for 5 years, then every year. After ten years of follow-up with no evidence of relapse, patients were usually referred to their general practitioner for the pursuit of the follow-up.

The biochemical relapse was defined as an elevation of the PSA level of at least $2 \mathrm{ng} / \mathrm{mL}$ above the nadir of the PSA levels, according to the Phoenix definition [30].

Treatment failure was defined as biochemical relapse, positive biopsy findings, or radiographic evidence of local disease progression or distant metastases. Failures were classified into biochemical relapse, local prostatic relapse or relapse in the seminal vesicles, pelvic nodal relapse, extra-pelvic nodal relapse, and metastatic relapse.

Patients who showed no evidence of treatment failure at the time of our analysis were classified as disease free.

\section{Statistics}

The association between progression free survival and each of the following variables was studied, using a Cox regression model: percentage of positive biopsies, location of positive biopsies (studying the apex involvement, base involvement, and median involvement), pre-treatment PSA serum level, Gleason score, clinical and radiological tumoral stage, clinical risk group, radiological risk group, adjunction of cytoreductive androgen deprivation therapy and its duration, D90 and V100. A Kaplan-Meier analysis was performed to generate progression free survival curves. The correlation between tumor location on MRI and on biopsies was tested using Pearson's chi squared test and Cohen's kappa statistic [31].

Statistical analysis was performed using $\mathrm{R}$ software ( $\mathrm{R}$ foundation for Statistical Computing, Vienna, Austria) [32-34].

\section{Results}

Of the 382 patients who were treated at our center between 2006 and 2013, 282 had detailed pre-treatment pathology reports and a minimum follow-up of 6 months, and were included.

The characteristics of the patients are presented in Table 1. Among the 282 patients, most patients $(69.9 \%)$ presented with a low-risk disease, according to the clinical D'Amico classification, modified by Zumsteg. The Gleason score was $6(3+3)$ for 213 patients $(75.5 \%)$, $7(3+4)$ for 52 patients $(18.4 \%)$, and $7(4+3)$ for eight patients $(2.8 \%)$. The median pre- treatment PSA serum level was $6.4 \mathrm{ng} / \mathrm{mL}$ (ranging from 0.9 to $17 \mathrm{ng} / \mathrm{mL}$ ).

The median number of prostate biopsies that were performed was 12 (ranging from 5 to 32). Targeted biopsies were realized for 28 patients (9.9\%). A total of 149 patients $(52.8 \%)$ had a disease involving the midgland; 131 (46.5\%) involving the apex, and 145 (51.4\%) involving the prostate base. The location was not detailed for 37 patients (13.1\%). Concerning percentage of positive biopsy cores, 262 patients (92.3\%) had less than 50\% positive biopsy cores, and $14(4.9 \%)$ had $50 \%$ or more positive biopsies. The information was not available for 6 patients $(2.1 \%)$. The median percentage of positive biopsy cores was $17 \%$ [3-75\%].

The prostatic volume evaluated initially on MRI, was available for 240 patients. The median value was $35 \mathrm{~cm}^{3}$ (ranging from 12 to $100 \mathrm{cc}$ ). The prostatic volume evaluated on the day of the procedure, with ultrasound imaging, was available for 203 patients, with a median value of $29.8 \mathrm{cc}$ (ranging from 10.5 to $62.2 \mathrm{cc}$ ).

One hundred and thirty-one patients (46\%) received androgen deprivation therapy before brachytherapy for cytoreduction purposes. The duration of the androgen deprivation therapy was 3 months in median (ranging from 0.5 to 12 months) for these patients. No patient received adjuvant androgen deprivation therapy.

The correlation between tumor location according to the MRI and tumor location according to the prostate biopsies was poor (with a Pearson's chi squared test $p$ value of 0.0033 , and a Cohen's kappa statistic of 0.1).

The median follow-up for the vital status was 64 months [12-140], and 61 months [5-137] for the progression status. The five-year progression free survival was 92.8\% (95\% confidence interval [89.3-96.3\%]) (Fig. 1). Twenty patients presented a progression, four were biochemical progressions only, seven were intra prostatic or seminal failures, five were pelvic nodal failures, one was an extra-pelvic nodal failure, and three were metastatic failures. The median time to progression was 39,5 months (ranging from 9 to 108 months). Two patients died, of causes unrelated to their prostate cancer (one from glioblastoma and one from ethylic cirrhosis). The characteristics of the relapse for the seven 
Table 1 Population characteristics

\begin{tabular}{|c|c|c|c|}
\hline Characteristics & Total population $(n=282)$ & Progression group $(n=20)$ & Progression-free group $(n=262)$ \\
\hline \multirow[t]{6}{*}{ Clinical risk group } & Low: 197 (69.8\%) & Low: 9 (45\%) & Low: 188 (71\%) \\
\hline & Intermediate: 83 (29.4\%) & Intermediate: 10 (50\%) & Intermediate: 73 (27.9\%) \\
\hline & Favorable intermediate: 67 (23\%) & Favorable intermediate: 8 (40\%) & Favorable intermediate: 59 (22\%) \\
\hline & $\begin{array}{l}\text { Unfavorable intermediate: } 16 \\
(5.6 \%)\end{array}$ & $\begin{array}{l}\text { Unfavorable intermediate: } 2 \\
(10 \%)\end{array}$ & Unfavorable intermediate: 14 (5\%) \\
\hline & High: 1 (0.3\%) & High: 0 & High: 1 (0.3\%) \\
\hline & NA: 1 & $N A: 1$ & \\
\hline \multirow[t]{6}{*}{ Radiological risk group } & Low: 158 (56\%) & Low: 9 (45\%) & Low: 150 (57.3\%) \\
\hline & Intermediate: 84 (29.7\%) & Intermediate: 10 (50\%) & Intermediate: 75 (28.6\%) \\
\hline & Favorable intermediate: 67 (23.7\%) & Favorable intermediate: 8 (40\%) & Favorable intermediate: 60 (22.9\%) \\
\hline & Unfavorable intermediate: 17 (6\%) & $\begin{array}{l}\text { Unfavorable intermediate: } 2 \\
(10 \%)\end{array}$ & $\begin{array}{l}\text { Unfavorable intermediate: } 15 \\
(5.7 \%)\end{array}$ \\
\hline & High: 33 (11.7\%) & High: 0 & High: 31 (11.8\%) \\
\hline & NA: 7 & NA: 1 & NA: 6 \\
\hline \multirow[t]{5}{*}{ Clinical Tumor stage } & T1c: 226 (80\%) & T1c: 15 (75\%) & T1c: 211 (80.5\%) \\
\hline & T2a: $50(17.7 \%)$ & T2a: 3 (15\%) & T2a: 47 (17.9\%) \\
\hline & T2b: 4 (1.4\%) & T2b: 1 (5\%) & T2b: 3 (1.1\%) \\
\hline & T2c: 1 (0.3\%) & T2c: 0 & T2c: 1 (0.3\%) \\
\hline & NA: 1 & NA: 1 & \\
\hline \multirow[t]{6}{*}{ Radiological Tumor stage } & T1c: 98 (34.7\%) & T1c: 5 (25\%) & T1c: 93 (35.5\%) \\
\hline & T2a: 124 (44\%) & T2a: 10 (50\%) & T2a: 114 (43.5\%) \\
\hline & T2b: 20 (7.1\%) & T2b: 2 (10\%) & T2b: 18 (6.9\%) \\
\hline & T2c: $32(11.3 \%)$ & T2c: 2 (10\%) & T2c: 30 (11.5\%) \\
\hline & T 3a: 1 (0.3\%) & Т 3a: 0 & T3a: 1 (0.3\%) \\
\hline & NA: 7 & $N A: 1$ & NA: 6 \\
\hline \multirow[t]{5}{*}{ Gleason score } & 4: $2(0.7 \%)$ & 4: 0 & 4: $2(0.8 \%)$ \\
\hline & $5: 7$ (2.5\%) & 5: $1(5 \%)$ & 5: $6(2.3 \%)$ \\
\hline & $6: 213(75.5 \%)$ & 6: $11(55 \%)$ & 6: $202(77.1 \%)$ \\
\hline & $7(3+4): 52(18.4 \%)$ & $7(3+4): 7(35 \%)$ & $7(3+4): 45(17.2 \%)$ \\
\hline & $7(4+3): 8(2.8 \%)$ & $7(4+3): 1(5 \%)$ & $7(4+3): 7(2.7 \%)$ \\
\hline Pre-treatment PSA serum level & 6.4 ng/mL [0.9-17] & $6.6[3.76-11.9]$ & $6.4[0.9-17]$ \\
\hline \multirow[t]{3}{*}{ Cytoreductive hormone therapy } & Yes: 131 (46.4\%) & Yes: 12 (60\%) & Yes: 119 (45.4\%) \\
\hline & No: 148 (52.4\%) & No: 8 (40\%) & No: 140 (53.4\%) \\
\hline & NA: 3 & & NA: 3 \\
\hline $\begin{array}{l}\text { Duration of cytoreductive hormone } \\
\text { therapy }\end{array}$ & 3 months [0.5-12] & 2 months [1-8] & 3 months [0.5-12] \\
\hline \multirow[t]{4}{*}{ Location of positive biopsy cores } & Base: 145 (51.4\%) & Base: 11 (55\%) & Base: 134 (51.1\%) \\
\hline & Midgland: 149 (52.8\%) & Midgland: 10 (50\%) & Midgland: 139 (53.1\%) \\
\hline & Apex: 131 (46.5\%) & Apex: 10 (50\%) & Apex: 121 (46.2\%) \\
\hline & NA: 37 & $N A: 3$ & NA: 34 \\
\hline \multirow[t]{4}{*}{ Percentage of positive biopsy cores } & Median: 17\% & Median: 17\% & Median: $17 \%$ \\
\hline & $<$ 50\%: $262(92.3 \%)$ & $<$ 50\%: $17(92.3 \%)$ & < 50\%: 245 (93.5\%) \\
\hline & $\geq$ 50\%: 14 (4.9\%) & $\geq 50 \%: 3$ (4.9\%) & $\geq 50 \%: 11$ (4.2\%) \\
\hline & $N A: 6$ & NA: 0 & NA: 6 \\
\hline Radiological location of tumor & None: 90 (31.9\%) & None: 5 (25\%) & None: 85 (32.4\%) \\
\hline
\end{tabular}


Table 1 Population characteristics (Continued)

\begin{tabular}{llll}
\hline Characteristics & Total population $(n=282)$ & Progression group $(n=20)$ & Progression-free group $(n=262)$ \\
\hline & Base: $72(25.5 \%)$ & Base: $8(40 \%)$ & Base: 64 (24.4\%) \\
& Midgland: $112(39.7 \%)$ & Midgland: $11(55 \%)$ & Midgland: $101(38.5 \%)$ \\
& Apex: $63(22.3 \%)$ & Apex: $6(30 \%)$ & NA: 15 \\
& NA: 16 & NA: 1 & \\
Yes: $20(7.1 \%)$ & & Yes: $2(0.7 \%)$ \\
Disease relapse & No: $262(92.9 \%)$ & No: $260(99 \%)$ \\
Yes: $2(0.7 \%)$ & Yes: 0 & $181[153-189]$ \\
Death & No: $280(99 \%)$, & No: 20 & $100[99-100]$ \\
Median D90 (Gy) & $181[153-189]$ & $181[171-189]$ & $49.2[31-65]$ \\
Median V100 (\%) & $100[99-100]$ & $100[99,7-100]$ & $196[168-240]$ \\
Median V150 (\%) & $49.2[31.5-64.8]$ & $200[182-226]$ & $182.9[102-212]$ \\
Median D10\% urethra & $196.5[168.6-240]$ & $183[165-205]$ & \\
Median D30\% urethra & $183[102.9-212.2]$ & &
\end{tabular}

Abbreviations: NA Not available

patients who presented an intra-prostatic or seminal failure are presented in Table 2.

The results of the univariate analysis are presented in Table 3. None of the studied covariates (percentage of positive biopsies, location of positive biopsies, pretreatment PSA serum level, Gleason score, clinical and radiological tumoral stage, clinical risk group, radiological risk group, adjunction of neo-adjuvant therapy and its duration, D90 and V100) was found to be significantly associated with the progression-free survival. There was a trend towards an association with progression-free survival for the clinical risk group $(\mathrm{HR}=1.73$ [0.99-3.03], $p=0.055)$, and for the Gleason score, when studied separating Gleason scores $<7$ and $\geq$ 7 (HR $=2.42$ [0.99-5.93], $p=0.053)$. We also noted that there were more patients with Gleason scores $\geq 7$ among

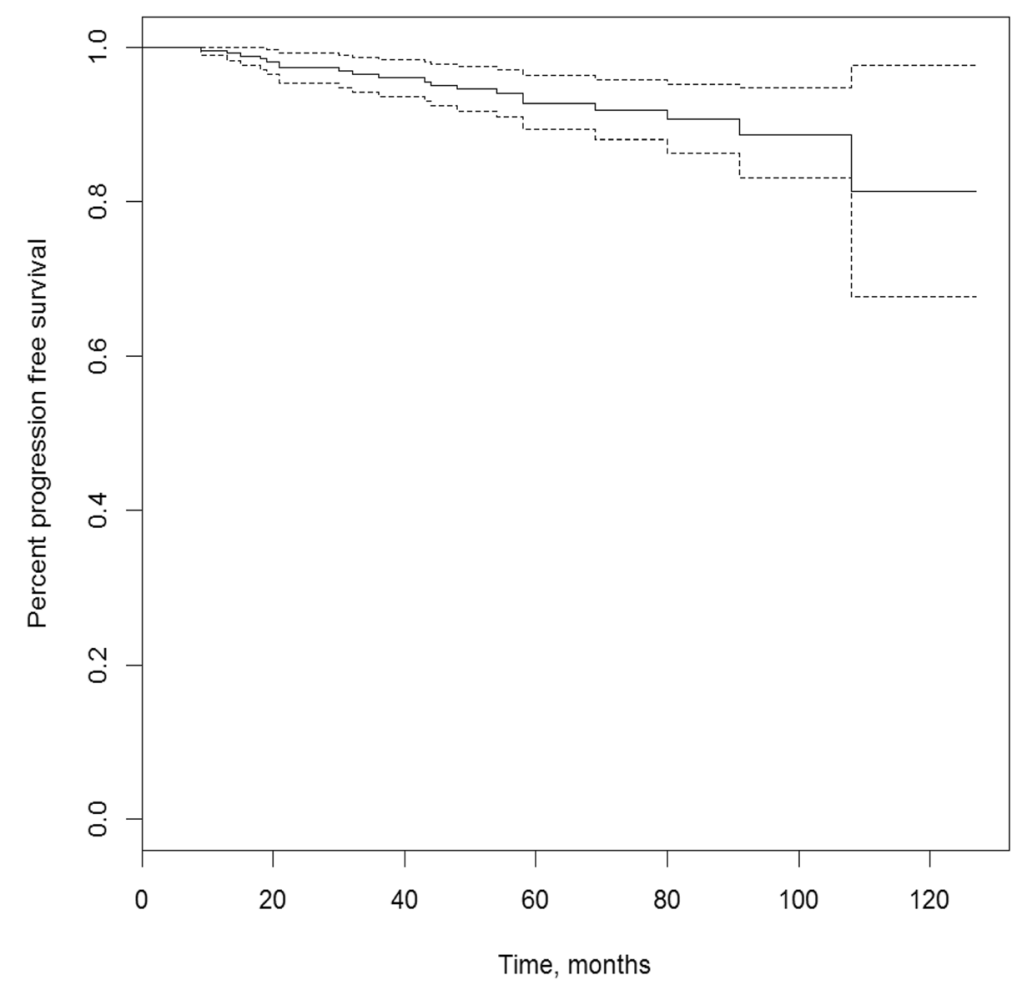

Fig. 1 Progression-free survival rate 


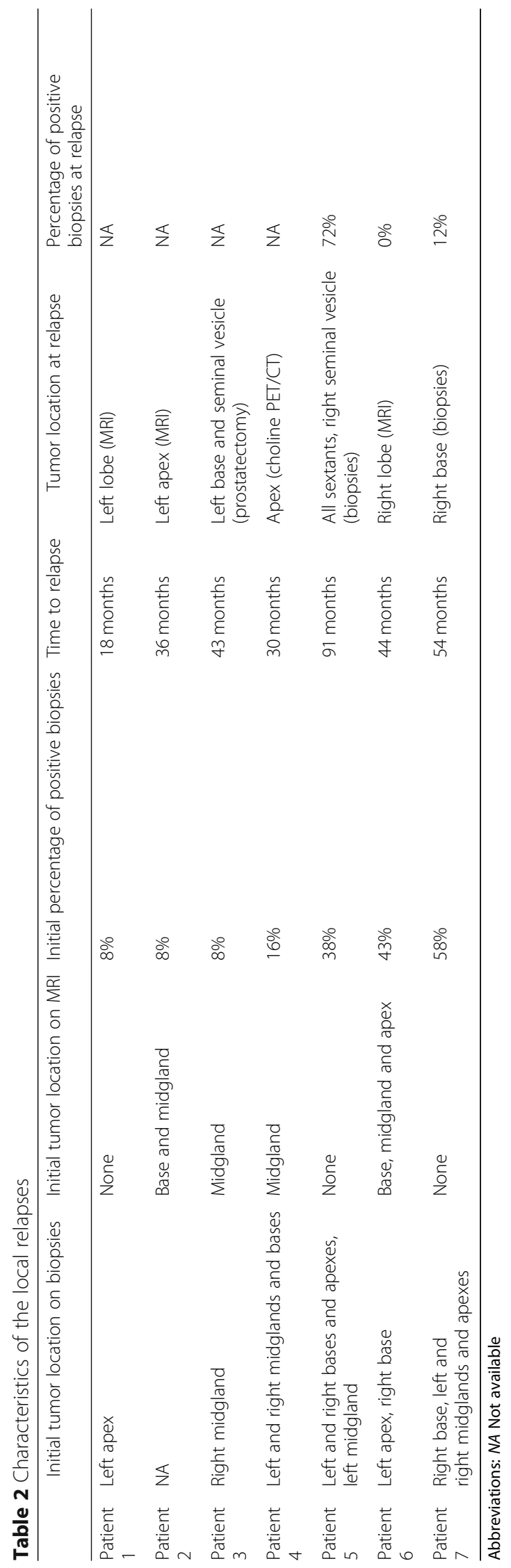


Table 3 Results of the univariate analysis

\begin{tabular}{llll}
\hline & HR & $95 \% \mathrm{Cl}$ & $p$-value \\
\hline Pre-treatment PSA & 1.09 & $0.92-1.29$ & 0.341 \\
Clinical tumor stage & 1.14 & $0.48-2.71$ & 0.765 \\
Radiological tumor stage & 1.12 & $0.71-1.75$ & 0.627 \\
Gleason score & 1.71 & $0.87-3.34$ & 0.115 \\
Gleason score (< or $\geq 7)$ & 2.42 & $0.98-5.93$ & 0.053 \\
Clinical risk group & 1.73 & $0.98-3.03$ & 0.055 \\
Radiological risk group & 1.17 & $0.78-1.75$ & 0.441 \\
Percentage of positive biopsies & 1.02 & $0.99-1.05$ & 0.191 \\
Percentage of positive biopsies ( $\leq$ or $>50 \%)$ & 2.34 & $0.53-10.15$ & 0.257 \\
Neo-adjuvant hormone therapy & 1.57 & $0.64-3.87$ & 0.323 \\
Duration of hormone therapy & 1.01 & $0.84-1.22$ & 0.887 \\
Apex involvement & 1.16 & $0.44-3.06$ & 0.758 \\
Midgland involvement & 0.83 & $0.31-2.19$ & 0.716 \\
Base involvement & 1.26 & $0.47-3.41$ & 0.6491 \\
D90 & 1.04 & $0.92-1.16$ & 0.5592 \\
V100 & 2.67 & $0.01-1055.7$ & 0.7479 \\
\hline
\end{tabular}

patients who progressed than among patients who did not progress $(40 \%$ vs $19 \%, p=0.042)$.

Among the 20 patients who experienced a progression, the different rescue treatment options were: androgen deprivation therapy (total androgen blockade) for 11 patients, prostatectomy for 2 patients, and stereotactic external beam radiation therapy for 2 patients (one on the prostate, and one on a lombo-aortic lymphadenopathy). The information was missing for five patients.

\section{Discussion}

Low-dose rate prostate brachytherapy is a very efficient treatment for localized prostate cancer, when patients are well selected.

Our results are consistent with other studies, with 5 year progression-free survival ranging from 85 to $97 \%$ for low risk prostate cancers [3, 7-10, 28, 35-38], and 75 to $94 \%$ for intermediate risk prostate cancers [7-10, 36, 37].

The oncological outcome is also comparable with other treatment modalities that can be proposed to patients with low to intermediate risk prostate cancers. The 5-year progression free survival rates for these patients range from 85 to $97 \%$ for radical prostatectomy [28, 35, 39], from 80 to $94.5 \%$ for high-dose external beam radiation therapy (74 Gy or more) [3, 39-42], and from 60 to $75 \%$ for active surveillance [43-45].

Rescue treatments with a curative intent after prostate brachytherapy are technically difficult. It is therefore very important to adequately select the patients who will benefit from brachytherapy.

Classical factors, such as PSA serum level, Gleason score, and tumor stage, which are taken into account in the risk groups according to D'Amico's classification, are used to select patients, as they have been proven to be associated with progression-free survival $[1,7,8,10,19$, 46-48]. Other factors, such as tumor location and tumor burden, might be associated with progression-freesurvival, and are frequently considered when selecting patients.

In our cohort, we were unable to identify a significant relationship between the percentage of positive biopsies and progression-free-survival, probably due to a lack of power but also possibly because of the difficulties we have in evaluating the tumor burden. This relationship between percentage of positive biopsies and biochemical outcome has been proven for prostate cancers treated by prostatectomy, or by external-beam radiation therapy [15]. It is not sure however if these results can be applied to brachytherapy. The tumor burden (expressed as percentage of positive biopsies, surface area positive for cancer, or number of positive cores) has been shown to be associated with extra-prostatic extension [49-54]. Compared to prostatectomy, brachytherapy enables an efficient treatment of the periprostatic tissues [55]. Concerning external-beam radiation therapy, the dose which can be delivered on the prostate might be insufficient in case of a high tumor burden, but this limitation could be overcome with brachytherapy, because it enables an important dose escalation on the prostate [56-58]. These two factors might be responsible for a potential lack of influence of tumor burden on biochemical outcome after brachytherapy.

The association between the local tumor burden and the biochemical outcome has already been studied for patients treated with brachytherapy in a few retrospective studies, but the results are discordant (Table 4) [16-20, 57-61]. Rossi et al. [17] found that patients with more than $50 \%$ of positive biopsies had a biochemical progression-free survival of 95\%, whereas patients with less than $50 \%$ of positive biopsies had a biochemical progression-free survival of only $63 \%(p<0.0001)$. Guzzo et al. [18] also noted that the percentage of positive biopsies was independently associated with the biochemical progression-free survival (when analyzed in a categorical fashion, with a threshold of $27 \%$, which was the median percentage of positive biopsies in their cohort). Grann et al. [16] found no association between the percentage of positive biopsies and biochemical progression-free survival, they did however find a tendency for an association between tumor length and biochemical progression-free survival $(p=0.15)$. Merrick et al. [57] found an association between percentage of positive biopsies and biochemical progression-free survival, but this association was not significant when stratifying patients by risk groups. On the other hand, Hill et al. [60], and Martell et al. [61] found no association between percentage of positive biopsies and biochemical progression-free survival. 
Table 4 Relationship between tumor burden and outcome in the literature

\begin{tabular}{|c|c|c|c|c|c|}
\hline & $\begin{array}{l}\text { Period of } \\
\text { recruitment }\end{array}$ & Number of patients & $\begin{array}{l}\text { Median number of } \\
\text { biopsy cores }\end{array}$ & $\begin{array}{l}\text { Median } \\
\text { follow-up }\end{array}$ & Outcome \\
\hline $\begin{array}{l}\text { Grann et al., } \\
1998[16]\end{array}$ & 1988-1994 & 103 & NA & 3 years & $\begin{array}{l}\text { 5-year bPFS }= \\
\mathrm{LT}<10 \mathrm{~mm}: 74 \% \\
\mathrm{LT}>10 \mathrm{~mm}: 36 \% \\
(p=0.011, \text { univariate } / p=0.15 \text { multivariate })\end{array}$ \\
\hline $\begin{array}{l}\text { Merrick et al., } \\
2002[57]\end{array}$ & 1995-1999 & $\begin{array}{l}262 \text { (111 with exclusive } \\
\text { brachytherapy) }\end{array}$ & $6(2-15)$ & $\begin{array}{l}38.6 \\
\text { months }\end{array}$ & $\begin{array}{l}\text { 5-year bPFS }=92.5 \% \\
\text { PPB }<34 \%: 96.6 \% \\
\text { PPB 34-50\%: } 92.9 \% \\
\text { PPB > 50\%: } 84.8 \% \\
(p=0.017) \\
\text { PPB not associated with bPFS within each risk } \\
\text { group. }\end{array}$ \\
\hline $\begin{array}{l}\text { Merrick et al., } \\
2004 \text { [58] }\end{array}$ & 1995-2001 & $\begin{array}{l}413 \text { (197 with exclusive } \\
\text { brachytherapy) }\end{array}$ & NA & 52 months & $\begin{array}{l}\text { 7-year bPFS = } \\
\text { PPB < 34\%: } 99.4 \% \\
\text { PPB 34-50\%: } 94.3 \% \\
\text { PPB > 50\%: } 89.2 \% \\
(p=0.002)\end{array}$ \\
\hline $\begin{array}{l}\text { Rossi et al., } \\
2006[17]\end{array}$ & 1997-1999 & 108 & 12 & 61 months & $\begin{array}{l}5 \text {-year bPFS }=87 \% \\
\text { PPB }<50 \%: 95 \% \\
\text { PPB }>50 \%: 63 \% \\
(p<0.0001)\end{array}$ \\
\hline $\begin{array}{l}\text { Guzzo et al., } \\
2008 \text { [18] }\end{array}$ & 1992-2002 & 245 & $6.8(1-18)$ & $\begin{array}{l}52.8 \\
\text { months }\end{array}$ & $\begin{array}{l}\text { 5-year bPFS: } 82 \% \\
\text { PPB < 27\%: } 89.1 \% \\
\text { PPB }>27 \%: 73.8 \% \\
(p=0.011)\end{array}$ \\
\hline $\begin{array}{l}\text { Merrick et al., } \\
2008[59]\end{array}$ & 1995-2004 & 145 & & 5.8 years & $\begin{array}{l}\text { 9-year bPFS }=97.1 \% \\
\mathrm{PPB}=\text { predictor of bPFS in multivariate analysis. }\end{array}$ \\
\hline $\begin{array}{l}\text { Potters et al., } \\
2008[19]\end{array}$ & 1992-2000 & 1449 & NA & 82 months & $\begin{array}{l}12-y e a r \text { bPFS }=78 \% \\
\text { PPB independently associated with bPFS in the } \\
\text { multivariate analysis }(p=0.037) \text {. }\end{array}$ \\
\hline $\begin{array}{l}\text { Taira et al., } \\
2011[20]\end{array}$ & 1995-2006 & $\begin{array}{l}1656 \text { ( } 831 \text { with exclusive } \\
\text { brachytherapy) }\end{array}$ & NA & 7 years & $\begin{array}{l}12-y e a r \text { bPFS }=95.6 \% \\
\text { PPB > 34\%: } 98 \% \\
\text { PPB 34-50\%: } 93 \% \\
\text { PPB > 50\%: } 91.5 \% \\
(p<0.001)\end{array}$ \\
\hline $\begin{array}{l}\text { Hill et al., } \\
2015[60]\end{array}$ & 1998-2012 & 846 & 12 & 5.59 years & $\begin{array}{l}\text { Biochemical failures: } 62 \text { (7.3\%) } \\
\text { Failures: } \mathrm{PPB}=32.8 \% \\
\text { Non failures: } \mathrm{PPB}=34.9 \% \\
\text { NS }\end{array}$ \\
\hline $\begin{array}{l}\text { Martell et al., } \\
2017 \text { [61] }\end{array}$ & 2003-2013 & 2608 & NA & 4,7 years & $\begin{array}{l}\text { Estimated 7-year-bPFS }=93 \% \\
\text { PPB not associated with bPFS. }\end{array}$ \\
\hline Present study & $2006-2013$ & 282 & $12(5-32)$ & 61 months & $\begin{array}{l}\text { Biochemical failures: } 20 \text { (7.1\%) } \\
\text { Failures: PPB }=17 \% \\
\text { Non failures: PPB }=17 \% \\
\text { NS }\end{array}$ \\
\hline
\end{tabular}

Abbreviations: bPFS biochemical Progression Free Survival, PPB Percentage of Positive Biopsies, LT length of tumor, NS Non significant

The adequate way to assess the tumor burden and its association with biochemical outcome is not well defined: either tumoral length, or percentage of positive biopsies, with different possible statistical analyses (linear, or categorical, with different possible thresholds $[16-18,20,57,58]$. Furthermore, one of the main issues in evaluating the local tumor burden with prostate biopsies is that there is an important sampling bias [62]. It seems that the more prostate biopsies are performed, the more accurate the percentage of prostate biopsies will be as a prognosis factor [18]. The number of biopsy cores performed has been shown to be an independent prognosis factor for patients treated with brachytherapy [63]. The realization of targeted prostate biopsies, becoming more frequent with the generalization of pre-biopsy procedure prostate MRI, also distorts the evaluation of tumor burden. These factors might contribute to explain why we did not find a significant association between percentage of positive biopsies and progression-freesurvival.

In daily practice, the percentage of positive biopsies is a factor that clinicians consider in their therapeutic choice. A survey made in 2007 in the 
USA found that radiation oncologists were influenced and more prone to treating patients with external beam radiation therapy, when positive biopsies increased from 30 to 50\% [64].

Concerning tumor location, only few authors have studied this aspect in patients treated with brachytherapy (Table 5). Hill et al. [60] found no significant association between base involvement and progression-free survival, but only a trend with a progression-free survival at ten years of $88.2 \%$ for patients with base involvement versus $92 \%$ for patients without base involvement. In a non-comparative retrospective study, Samuelian et al. [65] found that patients with base involvement treated with exclusive brachytherapy had a good disease control, with a progression-free survival of $93.5 \%$ at 10 years.

Yet, in prostate brachytherapy, the prostate base has been shown to be less well covered [22], with several technical limitations potentially explaining this underdosage. A correlation seems to exist between dosimetric quality and biochemical outcome [27, 66, 67], but this correlation might not be linear [68]. This could explain the good results observed even for cancers located at the prostate base, despite an underdosage of this location.

Furthermore, among low-risk prostate cancer, there seems to be very few tumors located in the anterior base of the prostate, which is not the case for intermediate risk prostate cancer [69]. These data might suggest that an underdosage of the prostate base would be of little consequence, at least for patients with low risk prostate cancer.

Our study did not show any association between tumor location and progression-free survival. Even though our study lacks the power to definitely conclude, it is a supplementary argument for safely proposing brachytherapy to patients with low to favorable-intermediate risk prostate cancer, regardless of the cancer location (except for technical contra-indications).
Even though we did not find any statistically significant associations with progression-free survival, we did however find two factors that presented a strong tendency towards an association with progression-free survival: the clinical risk group according to the D'Amico classification modified by Zumsteg, and the Gleason score (with a HR of 2.42 [0.99-5.93] for a Gleason score $\geq 7$ vs $<7$ ).

These results are consistent with previous studies which found an association of the Gleason score, the tumoral stage, the pre-treatment PSA serum level, or the risk group, with the progression-free survival. Several studies found an association, which is expected, between risk groups and progression-free survival $[1,7,8,19]$. The PSA serum level, is also often found to be associated with progression-free survival $[7,8,10,19,46,47]$, but this association is most often described when comparing PSA values of more than $20 \mathrm{ng} / \mathrm{mL}$ (which would currently constitute a contra-indication for brachytherapy) with PSA values of $20 \mathrm{ng} / \mathrm{mL}$ or less. The Gleason score is also found to be independently associated with progression-free survival $[10,19,48]$, as well as the tumoral stage, with worse outcomes described for stages T3 [8] or T2b and more [10, 46].

The strengths of our study are the important size of the cohort, and the non-selective recruitment of patients (consecutive patients treated between 2006 and 2013 were included). The monocentric character of our study also ensures that all patients received the same treatment according to the same protocol. However, our study has some limitations that should be considered. The low number of events (because of the low progression rates) does not grant us a significant amount of power to definitely conclude. The retrospective nature of our study, and the important number of patients who were excluded from our analysis (mainly because of unavailable pathology

Table 5 Relationship between tumor location and outcome in the literature

\begin{tabular}{|c|c|c|c|c|c|c|}
\hline & $\begin{array}{l}\text { Period of } \\
\text { recruitment }\end{array}$ & $\begin{array}{l}\text { Number of } \\
\text { patients }\end{array}$ & $\begin{array}{l}\text { Median number of } \\
\text { biopsy cores }\end{array}$ & $\begin{array}{l}\text { Tumor } \\
\text { location }\end{array}$ & $\begin{array}{l}\text { Median } \\
\text { follow-up }\end{array}$ & Outcome \\
\hline $\begin{array}{l}\text { Samuelian et al., } \\
2011 \text { [65] }\end{array}$ & 1998-2006 & 52 & 7 & BI: 52 & 89 months & 10 -year bPFS $=93.5 \%$ \\
\hline $\begin{array}{l}\text { Hill et al., } \\
2015 \text { [60] }\end{array}$ & 1998-2012 & 846 & 12 & $\begin{array}{l}\text { Bl: } 528 \\
\text { Ml: } 578 \\
\text { Al: } 560 \\
\text { Non Bl: } \\
318\end{array}$ & 5.59 years & $\begin{array}{l}\text { Biochemical failures: } 62(7.3 \%) \\
\text { Bl: } 42 / 62(67.7 \%) \\
\text { No Bl: } 20 / 62(32.3 \%) \\
(p=0.17)\end{array}$ \\
\hline Present study & 2006-2013 & 282 & 12 & $\begin{array}{l}\text { BI: } 145 \\
\text { MI: } 149 \\
\text { Al: } 131\end{array}$ & 61 months & $\begin{array}{l}\text { Biochemical failures: } 20 \text { (7.1\%) } \\
\text { Failures: BI } 11 \text { patients }(55 \%) / \text { MI } 10 \text { (50\%) / Al } \\
10 \text { (50\%) } \\
\text { Non failures: Bl } 134 \text { patients (51.1\%)/ MI } 139 \\
\text { (53.1\%)/ Al } 121 \text { (46.2\%) } \\
\text { NS }\end{array}$ \\
\hline
\end{tabular}


reports) are other limitations. Also, the five-year median follow-up was probably too short to account for a large number of events.

\section{Conclusions}

Brachytherapy is an efficient treatment for localized prostate cancer when patients are selected with classical criteria (low to favorable intermediate risk prostate cancer). In this cohort of 282 patients, we did not find any significant association between either tumor location or percentage of positive biopsies, and progression-freesurvival. We did, however, find a strong trend towards an association of both the clinical risk group (according to the D'Amico classification modified by Zumsteg) and the Gleason score, with progression-free survival. Although our study lacks the power to definitely conclude, these results support the continued use of brachytherapy, with no limitation regarding tumor location, for patients with low-risk and selected favorable intermediate risk prostate cancers (remaining cautious with these patients and not cumulating risk factors).

\section{Acknowledgments}

Not applicable.

\section{Authors' contributions}

$\mathrm{CM}$ collected the data and wrote the article. $\mathrm{AH}$ designed the work and revised the article. ST contributed to the data collection. SU analyzed the data. CD, QD, MOT and AM revised the article. NT and PG designed the work and revised the article. All authors read and approved the final manuscript.

\section{Funding}

The authors acknowledge that they received no external funding in support of this research.

\section{Availability of data and materials}

The datasets used and/or analysed during the current study are available from the corresponding author on reasonable request.

\section{Ethics approval and consent to participate}

All patients were informed that their data could potentially be used for anonymised studies. Our study was approved by the committee of ethics and clinical research of the European Hospital Georges Pompidou, in the context of the authorization by the CNIL (Commission Nationale de I'Informatique et des Libertés) number 1922081, dated February 2nd 2016. Patients' consent was not considered necessary, given the retrospective nature of the study and the anonymisation of all data.

\section{Consent for publication}

Not applicable.

\section{Competing interests}

The authors declare that they have no competing interests.

\section{Author details}

${ }^{1}$ Hôpital Européen Georges Pompidou, 20 rue Leblanc, 75015 Paris, France. ¿Unité de Recherche Clinique, Hôpital Tarnier, 89 rue d'Assas, 75006 Paris, France.
Received: 21 October 2019 Accepted: 18 December 2019

Published online: 31 December 2019

\section{References}

1. Stone NN, Stock RG, Unger P. Intermediate term biochemical-free progression and local control following 125iodine brachytherapy for prostate cancer. J Urol. 2005;173(3):803-7.

2. Kupelian PA, Potters L, Khuntia D, Ciezki JP, Reddy CA, Reuther AM, et al. Radical prostatectomy, external beam radiotherapy $<72$ Gy, external beam radiotherapy $>$ or $=72 \mathrm{~Gy}$, permanent seed implantation, or combined seeds/external beam radiotherapy for stage T1-T2 prostate cancer. Int J Radiat Oncol Biol Phys. 2004;58(1):25-33.

3. Zelefsky MJ, Yamada Y, Pei X, Hunt M, Cohen G, Zhang Z, et al. Comparison of tumor control and toxicity outcomes of high-dose intensity-modulated radiotherapy and brachytherapy for patients with favorable risk prostate cancer. Urology. 2011;77(4):986-90.

4. Rodrigues $G$, Yao X, Loblaw DA, Brundage M, Chin JL. Low-dose rate brachytherapy for patients with low- or intermediate-risk prostate cancer: a systematic review. Can Urol Assoc J J Assoc Urol Can. 2013;7(11-12):463-70.

5. Kittel JA, Reddy CA, Smith KL, Stephans KL, Tendulkar RD, Ulchaker J, et al. Long-term efficacy and toxicity of low-dose-rate ${ }^{125}$ I prostate brachytherapy as monotherapy in low-, intermediate-, and high-risk prostate cancer. Int J Radiat Oncol Biol Phys. 2015;92(4):884-93.

6. Crook JM, Gomez-Iturriaga A, Wallace K, Ma C, Fung S, Alibhai S, et al. Comparison of health-related quality of life 5 years after SPIRIT: surgical prostatectomy versus interstitial radiation intervention trial. J Clin Oncol Off J Am Soc Clin Oncol. 2011;29(4):362-8.

7. Grimm PD, Blasko JC, Sylvester JE, Meier RM, Cavanagh W. 10-year biochemical (prostate-specific antigen) control of prostate cancer with 1251 brachytherapy. Int J Radiat Oncol. 2001;51(1):31-40.

8. Lazarev S, Thompson MR, Stone NN, Stock RG. Low-dose-rate brachytherapy for prostate cancer: outcomes at >10 years of follow-up. BJU Int. 2018;121(5):781-90.

9. Sylvester JE, Grimm PD, Wong J, Galbreath RW, Merrick G, Blasko JC. Fifteenyear biochemical relapse-free survival, cause-specific survival, and overall survival following I(125) prostate brachytherapy in clinically localized prostate cancer: Seattle experience. Int J Radiat Oncol Biol Phys. 2011;81(2):376-81.

10. Zelefsky MJ, Kuban DA, Levy LB, Potters L, Beyer DC, Blasko JC, et al. Multiinstitutional analysis of long-term outcome for stages T1-T2 prostate cancer treated with permanent seed implantation. Int J Radiat Oncol Biol Phys. 2007;67(2):327-33

11. Mottet N, Bellmunt J, Bolla M, Briers E, Cumberbatch MG, De Santis M, et al. EAU-ESTRO-SIOG guidelines on prostate cancer. Part 1: screening, diagnosis, and local treatment with curative intent. Eur Urol. 2017;71(4):618-29.

12. Davis BJ, Horwitz EM, Lee WR, Crook JM, Stock RG, Merrick GS, et al. American Brachytherapy Society consensus guidelines for transrectal ultrasound-guided permanent prostate brachytherapy. Brachytherapy. 2012;11(1):6-19.

13. Heidenreich A, Bastian PJ, Bellmunt J, Bolla M, Joniau S, van der Kwast T, et al. EAU guidelines on prostate cancer. Part 1: screening, diagnosis, and local treatment with curative intent-update 2013. Eur Urol. 2014;65(1):124-37.

14. Professionals S-O. EAU Guidelines: Prostate Cancer [Internet]. Uroweb. Available from: https://uroweb.org/guideline/prostate-cancer/\#11. [cited 2019 Jun 12].

15. D'Amico AV, Whittington R, Malkowicz SB, Schultz D, Silver B, Henry L, et al. Clinical utility of percent-positive prostate biopsies in predicting biochemical outcome after radical prostatectomy or external-beam radiation therapy for patients with clinically localized prostate cancer. Mol Urol. 2000;4(3):171-5 discussion 177.

16. Grann A, Gaudin PB, Raben A, Wallner K. Pathologic features from prostate needle biopsy and prognosis after 1-125 brachytherapy. Radiat Oncol Investig. 1998;6(4):170-4.

17. Rossi PJ, Clark PE, Papagikos MA, McCullough DL, Lee WR. Percentage of positive biopsies associated with freedom from biochemical recurrence after low-dose-rate prostate brachytherapy alone for clinically localized prostate cancer. Urology. 2006;67(2):349-53.

18. Guzzo TJ, Levin BM, Lee R, Guo M, Chen Z, Whittington R, et al. Relationship of biochemical outcome to percentage of positive biopsies in men with clinically localized prostate cancer treated with permanent interstitial brachytherapy. Urology. 2008;71(4):723-7.

19. Potters L, Morgenstern C, Calugaru E, Fearn P, Jassal A, Presser J, et al. 12year outcomes following permanent prostate brachytherapy in patients with clinically localized prostate cancer. J Urol. 2008;179(5 Suppl):S20-4. 
20. Taira AV, Merrick GS, Butler WM, Galbreath RW, Lief J, Adamovich E, et al. Longterm outcome for clinically localized prostate cancer treated with permanent interstitial brachytherapy. Int J Radiat Oncol Biol Phys. 2011;79(5):1336-42.

21. Ellis WJ. Prostate brachytherapy. Cancer Metastasis Rev. 2002;21(2):125-9.

22. Nasser NJ, Wang Y, Borg J, Saibishkumar EP. Sector analysis of dosimetry of prostate cancer patients treated with low-dose-rate brachytherapy. Brachytherapy. 2014;13(4):369-74.

23. Keyes M, Miller S, Moravan V, Pickles T, McKenzie M, Pai H, et al. Predictive factors for acute and late urinary toxicity after permanent prostate brachytherapy: long-term outcome in 712 consecutive patients. Int I Radiat Oncol Biol Phys. 2009;73(4):1023-32.

24. Liu D, Usmani N, Ghosh S, Kamal W, Pedersen J, Pervez N, et al. Comparison of prostate volume, shape, and contouring variability determined from preimplant magnetic resonance and transrectal ultrasound images. Brachytherapy. 2012;11(4):284-91.

25. Pinkawa M, Gagel B, Asadpour B, Piroth MD, Klotz J, Borchers H, et al. Seed displacements after permanent brachytherapy for prostate cancer in dependence on the prostate level. Strahlenther Onkol Organ Dtsch Rontgengesellschaft Al. 2008;184(10):520-5.

26. Sidhu S, Morris WJ, Spadinger I, Keyes M, Hilts M, Harrison R, et al. Prostate brachytherapy postimplant dosimetry: a comparison of prostate quadrants. Int J Radiat Oncol Biol Phys. 2002;52(2):544-52.

27. Nath S, Chen Z, Yue N, Trumpore S, Peschel R. Dosimetric effects of needle divergence in prostate seed implant using $125 \mathrm{I}$ and 103Pd radioactive seeds. Med Phys. 2000;27(5):1058-66.

28. D'Amico AV, Whittington R, Malkowicz SB, Schultz D, Blank K, Broderick GA, et al. Biochemical outcome after radical prostatectomy, external beam radiation therapy, or interstitial radiation therapy for clinically localized prostate cancer. JAMA. 1998;280(11):969-74

29. Zumsteg ZS, Spratt DE, Pei I, Zhang Z, Yamada Y, Kollmeier M, et al. A new risk classification system for therapeutic decision making with intermediaterisk prostate cancer patients undergoing dose-escalated external-beam radiation therapy. Eur Urol. 2013;64(6):895-902

30. Roach M, Hanks G, Thames H, Schellhammer P, Shipley WU, Sokol GH, et al. Defining biochemical failure following radiotherapy with or without hormonal therapy in men with clinically localized prostate cancer: recommendations of the RTOG-ASTRO Phoenix Consensus Conference. Int J Radiat Oncol Biol Phys. 2006;65(4):965-74.

31. McHugh ML. Interrater reliability: the kappa statistic. Biochem Medica. 2012; 22(3):276-82.

32. R: The R Project for Statistical Computing [Internet]. Available from: https:// www.r-project.org/. [cited 2019 Jun 24].

33. Therneau TM, Grambsch PM. Modeling survival data: extending the cox model [internet]. New York: Springer-Verlag; 2000. (Statistics for Biology and Health). Available from: https://www.springer.com/gp/book/9780387987842 [cited 2019 Jun 24]

34. Falissard B. psy: Various procedures used in psychometry [Internet]. 2012. Available from: https://CRAN.R-project.org/package=psy. [cited 2019 Nov 28].

35. Giberti C, Chiono L, Gallo F, Schenone M, Gastaldi E. Radical retropubic prostatectomy versus brachytherapy for low-risk prostatic cancer: a prospective study. World J Urol. 2009;27(5):607-12.

36. Blasko JC, Grimm PD, Sylsvester JE, Cavanagh W. The role of external beam radiotherapy with I-125/Pd-103 brachytherapy for prostate carcinoma. Radiother Oncol J Eur Soc Ther Radiol Oncol. 2000;57(3):273-8.

37. Cosset J-M, Flam T, Thiounn N, Gomme S, Rosenwald J-C, Asselain B, et al. Selecting patients for exclusive permanent implant prostate brachytherapy: the experience of the Paris Institut Curie/Cochin Hospital/Necker Hospital group on 809 patients. Int J Radiat Oncol Biol Phys. 2008;71(4):1042-8.

38. Lawton CA, DeSilvio M, Lee WR, Gomella L, Grignon D, Gillin M, et al. Results of a phase II trial of transrectal ultrasound-guided permanent radioactive implantation of the prostate for definitive management of localized adenocarcinoma of the prostate (radiation therapy oncology group 98-05). Int J Radiat Oncol Biol Phys. 2007;67(1):39-47.

39. Hamdy FC, Donovan JL, Lane JA, Mason M, Metcalfe C, Holding P, et al. 10year outcomes after monitoring, surgery, or radiotherapy for localized prostate cancer. N Engl J Med. 2016:375(15):1415-24.

40. Zietman AL, Bae K, Slater JD, Shipley WU, Efstathiou JA, Coen JJ, et al. Randomized trial comparing conventional-dose with high-dose conformal radiation therapy in early-stage adenocarcinoma of the prostate: long-term results from proton radiation oncology group/american college of radiology 95-09. J Clin Oncol Off J Am Soc Clin Oncol. 2010;28(7):1106-11.
41. Heemsbergen WD, Al-Mamgani A, Slot A, Dielwart MFH, Lebesque JV. Longterm results of the Dutch randomized prostate cancer trial: impact of doseescalation on local, biochemical, clinical failure, and survival. Radiother Oncol J Eur Soc Ther Radiol Oncol. 2014;110(1):104-9.

42. Michalski JM, Moughan J, Purdy J, Bosch W, Bruner DW, Bahary J-P, et al. Effect of standard vs dose-escalated radiation therapy for patients with intermediate-risk prostate Cancer: the NRG oncology RTOG 0126 randomized clinical trial. JAMA Oncol. 2018;4(6):e180039.

43. Adamy A, Yee DS, Matsushita K, Maschino A, Cronin A, Vickers A, et al. Role of prostate specific antigen and immediate confirmatory biopsy in predicting progression during active surveillance for low risk prostate cancer. J Urol. 2011;185(2):477-82.

44. Klotz L, Vesprini D, Sethukavalan P, Jethava V, Zhang L, Jain S, et al. Longterm follow-up of a large active surveillance cohort of patients with prostate cancer. J Clin Oncol Off J Am Soc Clin Oncol. 2015;33(3):272-7.

45. Tosoian JJ, Mamawala M, Epstein JI, Landis P, Wolf S, Trock BJ, et al. Intermediate and longer-term outcomes from a prospective activesurveillance program for favorable-risk prostate cancer. J Clin Oncol. 2015; 33(30):3379-85.

46. Stock RG, Stone NN, DeWyngaert JK, Lavagnini P, Unger PD. Prostate specific antigen findings and biopsy results following interactive ultrasound guided transperineal brachytherapy for early stage prostate carcinoma. Cancer. 1996;77(11):2386-92

47. Wallner K, Roy J, Harrison L. Tumor control and morbidity following transperineal iodine 125 implantation for stage T1/T2 prostatic carcinoma. J Clin Oncol Off J Am Soc Clin Oncol. 1996;14(2):449-53.

48. Stone NN, Stone MM, Rosenstein BS, Unger P, Stock RG. Influence of pretreatment and treatment factors on intermediate to long-term outcome after prostate brachytherapy. J Urol. 2011;185(2):495-500.

49. Sebo TJ, Bock BJ, Cheville JC, Lohse C, Wollan P, Zincke H. The percent of cores positive for cancer in prostate needle biopsy specimens is strongly predictive of tumor stage and volume at radical prostatectomy. J Urol. 2000; 163(1):174-8.

50. Wills ML, Sauvageot J, Partin AW, Gurganus R, Epstein Jl. Ability of sextant biopsies to predict radical prostatectomy stage. Urology. 1998;51(5):759-64.

51. Ogawa O, Egawa S, Arai Y, Tobisu K, Yoshida O, Kato T. Preoperative predictors for organ-confined disease in Japanese patients with stage T1C prostate cancer. Int J Urol Off J Jpn Urol Assoc. 1998:5(5):454-8.

52. Peller PA, Young DC, Marmaduke DP, Marsh WL, Badalament RA. Sextant prostate biopsies. A histopathologic correlation with radical prostatectomy specimens. Cancer. 1995;75(2):530-8.

53. Badalament RA, Miller MC, Peller PA, Young DC, Bahn DK, Kochie P, et al. An algorithm for predicting nonorgan confined prostate cancer using the results obtained from sextant core biopsies with prostate specific antigen level. J Urol. 1996;156(4):1375-80.

54. Graefen M, Haese A, Pichlmeier U, Hammerer PG, Noldus J, Butz K, et al. A validated strategy for side specific prediction of organ confined prostate cancer: a tool to select for nerve sparing radical prostatectomy. J Urol. 2001;165(3):857-63.

55. Merrick GS, Butler WM, Wallner KE, Burden LR, Dougherty JE. Extracapsular radiation dose distribution after permanent prostate brachytherapy. Am J Clin Oncol. 2003:26(5):e178-89.

56. Nurani R, Wallner K, Merrick G, Virgin J, Orio P, True LD. Optimized prostate brachytherapy minimizes the prognostic impact of percent of biopsy cores involved with adenocarcinoma. J Urol. 2007;178(5):1968-73 discussion 1973.

57. Merrick GS, Butler WM, Galbreath RW, Lief JH, Adamovich E. Relationship between percent positive biopsies and biochemical outcome after permanent interstitial brachytherapy for clinically organ-confined carcinoma of the prostate gland. Int J Radiat Oncol Biol Phys. 2002;52(3):664-73.

58. Merrick GS, Butler WM, Wallner KE, Galbreath RW, Lief JH, Adamovich E. Prognostic significance of percent positive biopsies in clinically organconfined prostate cancer treated with permanent prostate brachytherapy with or without supplemental external-beam radiation. Cancer J Sudbury Mass. 2004;10(1):54-60

59. Merrick GS, Wallner KE, Galbreath RW, Butler WM, Brammer SG, Allen ZA, et al. Prostate brachytherapy in men $>$ or $=75$ years of age. Int J Radiat Oncol Biol Phys. 2008;72(2):415-20.

60. Hill J, Hackett C, Sloboda R, Menon G, Singhal S, Pervez N, et al. Does location of prostate cancer by sextant biopsies predict for relapse after (125) I seed implant brachytherapy? Brachytherapy. 2015;14(6):788-94.

61. Martell K, Husain S, Taussky D, Angyalfi S, Delouya G, Després P, et al. Multicenter evaluation of biochemical relapse-free survival outcomes for 
intraoperatively planned prostate brachytherapy using an automated delivery system. Int J Radiat Oncol Biol Phys. 2017;99(4):895-903.

62. Cupp MR, Bostwick DG, Myers RP, Oesterling JE. The volume of prostate cancer in the biopsy specimen cannot reliably predict the quantity of cancer in the radical prostatectomy specimen on an individual basis. J Urol. 1995;153(5):1543-8.

63. Bittner N, Merrick GS, Galbreath RW, Butler WM, Adamovich E, Wallner KE. Greater biopsy core number is associated with improved biochemical control in patients treated with permanent prostate brachytherapy. Int J Radiat Oncol Biol Phys. 2010;78(4):1104-10.

64. Frank SJ, Grimm PD, Sylvester JE, Merrick GS, Davis BJ, Zietman A, et al. Interstitial implant alone or in combination with external beam radiation therapy for intermediate-risk prostate cancer: a survey of practice patterns in the United States. Brachytherapy. 2007;6(1):2-8.

65. Samuelian JM, Swanson DA, Kudchadker RJ, Pugh TJ, Kuban DA, Lee AK, et al. Long-term tumor control after brachytherapy for base-of-prostate cancer. J Contemp Brachytherapy. 2011;3(4):183-7.

66. Kollmeier MA, Stock RG, Stone N. Biochemical outcomes after prostate brachytherapy with 5-year minimal follow-up: importance of patient selection and implant quality. Int J Radiat Oncol Biol Phys. 2003;57(3):645-53.

67. Ash D, Al-Qaisieh B, Bottomley D, Carey B, Joseph J. The correlation between D90 and outcome for $1-125$ seed implant monotherapy for localised prostate cancer. Radiother Oncol J Eur Soc Ther Radiol Oncol. 2006;79(2):185-9.

68. Spadinger I, Morris WJ, Keyes M, Liu M, Shaffer R, Thompson A, et al. Quadrant dosimetry as a predictor of biochemical relapse in 125 l prostate brachytherapy. Brachytherapy. 2011;10(2):87-97.

69. D'Amico AV, Davis A, Vargas SO, Renshaw AA, Jiroutek M, Richie JP. Defining the implant treatment volume for patients with low risk prostate cancer: does the anterior base need to be treated? Int I Radiat Oncol Biol Phys. 1999;43(3):587-90.

\section{Publisher's Note}

Springer Nature remains neutral with regard to jurisdictional claims in published maps and institutional affiliations.

Ready to submit your research? Choose BMC and benefit from:

- fast, convenient online submission

- thorough peer review by experienced researchers in your field

- rapid publication on acceptance

- support for research data, including large and complex data types

- gold Open Access which fosters wider collaboration and increased citations

- maximum visibility for your research: over $100 \mathrm{M}$ website views per year

At $\mathrm{BMC}$, research is always in progress.

Learn more biomedcentral.com/submissions 